\title{
Egyptian Islamic Banks' Social Reporting: Is there Change?
}

\author{
Dr. Mohamed Nagy Osman \\ Lecturer of Accounting, Faculty of Commerce \\ Benha University, Egypt \\ E-mail: Mohamedossman@gmail.com
}




\section{Egyptian Islamic Banks' Social Reporting: Is there Change?}

Keywords: Social Reporting, Arab Uprisings, Change, Egypt, Islamic Banks, Legitimacy 


\section{Introduction}

Globlisation brings positive and negative potentialities to developing countries (Hopper et al., 2017). The Arab world has erupted the world with different uprisings since 2010 asking for a change of political leadership as a result of corruption, low level of living, social injustice, human rights violations, and unsatisfactory financial growth (Abumustafa, 2016). The Arab uprisings have affected the region's business environment, particularly in how local companies are expected to behave and respond to increasing social expectations, new social influencers, and changes in societal values and potential consumer behaviours (Avia, 2013). A critical form of these companies is Islamic banks. Over the last 30 years, Islamic banks have gained global acceptance and permeated into international investment markets $50 \%$ quicker than the rest of the banking sector, and they expect to continue growing. They even successfully averted the 2007-2008 global financial crisis, though they nevertheless encountered various financial problems (Ben Khediri et al., 2015).

A few studies in the literature explored social reporting of Islamic banks in the Islamic and Arab countries on annual reports (Maali et al., 2006; Haniffa and Hudaib, 2007; Hassan and Harab, 2010; Farook et al., 2011; Aribi and Gao, 2010, 2012; Megeid, 2013; Khan, 2013). Only Kamla and Rammal (2013) investigated the social reporting of Islamic banks on websites and annual reports. No study explored how Islamic banks responded to the increasing social expectations of Egyptian community after the Arab uprisings on Websites and press releases. Thus, this research investigates the volume, quality and nature of social reporting practices of Islamic banks in Egypt - Muslim Arab spring country - on websites and annual reports before and after Arab uprisings in Egypt.

Islamic banks are based on Islamic Sharia law, which prioritize issues concerning social justice, the environment, and general well-being (Kamla et al., 2006). Thus such banks within the Islamic community are expected to satisfy their social responsibilities but also report on their own activities and performance. Additionally, Muslims living in the Islamic communities where Islamic banks operate usually hold high expectations of these banks' social role (Maali et al., 2006). Islamic banks do not apply riba (interest), as well as prohibit exploitation and ghrar (uncertainty) in financial transactions (Aggarwal and Yousef, 2000). Lewis (2001, p. 119) says ghrar means to 
"undertake a venture blindly without sufficient knowledge or to undertake an excessively risky transaction. By failing or neglecting to define any of the essential pillars of contract relating to the consideration or measure of the object, the parties undertake a risk which is not indispensable for them". Therefore, this kind of investment is prohibited because of its inherent risk. Moreover, Islamic banks value correlation with the real economy and are governed by the concept of Profit and Loss Sharing (PLS) (Warde, 2013). PLS - the "contractual arrangement between two or more transacting parties, which allow them to pool their resources to invest in a project to share in profit and loss" (Dar and Presely, 2000, p.4) - is fundamental in Islamic banking. Islamic banks offer several predominantly Islamic finance products: Murbaha (a contract whereby the client specifies the goods he/she wants to buy then the bank purchases it and offers its resale to the client with an agreed profit markup); Mudaraba (an association between two parties, one providing labour and the other providing capital with profits shared according to a prearranged percentage - though in case of loss the capital provider conveys all financial losses up to the invested amount while the other partner will take no returns of his/her work); Musharakah (a kind of partnership); and Quard Hassan (loan repayment by low-income earners over an agreed period of time without the bank collecting any profits) (Kamla, 2009; Faisal Islamic Bank of Egypt, 2016). Further, Islamic banks can offer products similar to those conventional banks do such as letters of guarantee and current accounts but only with the condition of adopting Islamic Sharia (Maali et al., 2006). Similarly, to guarantee that clients' religious needs and expectations are met, the bank appoints a Sharia Supervisory Board to report whether the banks' activities comply with Islamic Sharia (Karim, 1990).

In the same vein, CSR in Islam entails a broader meaning that incorporates a Taqwa dimension (God-consciousness) through which companies assume the roles and responsibilities of servants and vicegerents in all conditions. Consequently, organisations as groups of individuals are obliged to God, the owner of their selves, and the resources they are utilizing and managing (Al-Attas, 1996). Islamic moral law (Sharia) governs all aspects of Muslim life: spiritual, economic, political and social, and duties and obligations (the faithful execution of these two) (Lewis, 2001). It is concerned with promoting social justice and 
welfare $^{(*)}$ in the community, as well as approaching God's blessings in this world and thereafter (Hassan and Hararhap, 2010). Furthermore, it entails different Islamic teachings that highlight the nature of business activity such as Adl (Justice), Amanah (Honesty), Brotherhood/Sisterhood, socio-economic justice, and satisfying the material and spiritual needs of all humans (Chapra, 1992). These Islamic concepts are considered the core of Corporate Social Responsibility (CSR) activities (Ullah and Jamali, 2010). Similarly, Zinkin (2007) stressed that Islamic teachings surpass the UN Global Compact's minimum standards. Accordingly, the tenets of CSR are not new to Islamic banks. The paper is structured as follows; the following section is literature review, then Egypt and Arab spring, Methodology, Findings, and conclusion.

\section{Literature Review}

There is growing interest in social reporting by Islamic banks with social responsibility seen as rooted in Sharia (Ullah and Jamali, 2010), with studies on: the relationship between CSR performance and the ability to attract institutional investors and customers (Dusuki and Abdullah, 2007); Islamic fund performance (Abdelsalam et al., 2014); CSR reporting quality visà-vis Islamic principles (Maali et al., 2006; Haniffa and Hudaib, 2007; Hassan and Harahap, 2010; Aribi and Gao, 2012; Kamla and Rammal, 2013; Khan, 2013); comparing Islamic and conventional banks' reporting (Aribi and Gao, 2010; Megeid, 2013); disclosure determinants (Farook et al., 2011). Only two studies have used interviews of Islamic bank senior managers to explore CSR drivers, (Belal et al., 2015; Aribi and Arun, 2015). No study has been conducted to examine changes in Islamic banks' social reporting before and after two revolutions in 2011 and 2013. This research adopts legitimacy theory to make interpretations of the results of this research. "Legitimacy is generalized perception on assumption that the actions of an entity are desirable, proper, or appropriate within some socially constructed system of norms, values, beliefs, and definitions" (Suchman, 1995, p.5). Legitimacy theory thus prioritizes the social contract (Deegan, 2002) whereby a company must consider the rights of the public, not only

$\left.{ }^{*}\right)$ Social welfare is promoted through Zakat. it is collected from Muslim individuals and businesses to be paid to the poor and the needy, to enhance community welfare. It is basically a redistribution of wealth (Lewis, 2001). 
investors. In this contract, failure to comply with social expectations tempts negative consequences (Deegan and Unerman, 2010). However, complying does not necessarily guarantee legitimacy. Indeed, an organization's legitimacy can be threatened even if its performance meets community expectations. For example, an organization's failure to disclose and report on its own compliance with societal expectations, which may change over time, can invite this (Deegan and Rankin, 1996). Consequently, companies usually try to avert such dangerous possibilities via different mediums such as annual reports, standalone reports, websites, and press releases (Patten, 1992; Aerts and Cormier, 2009). Overall, then, they embrace different strategies to gain, maintain or repair legitimacy (known as legitimation strategies) (Cho, 2009). This research has three fold contributions. First, it contributes to social reporting of Islamic banks by examining change in Islamic banks' social reporting in annual reports and websites pre and post two Arab uprisings in Egypt as a result of social injustice and corruption; by exploring changes in volume, quality, and nature of Islamic banks' social reporting practices. Second, it complements research on corporate responses to social and political events (O'Donovan, 2002; Aerts and Cormier, 2009; Cho, 2009; Uddin et al., 2016; Yekini et al., 2017). Third, it contributes to social reporting literature in emerging economies of different companies, which are different from the Western world (Hopper et al., 2017; Fuzi et al., 2013). The next section hunts Egypt context and Arab spring.

\section{Egypt and Arab Spring}

The Egyptian revolution is one of the most critical and influential movements in the Arab spring, with its impact influencing its geopolitical position and inspiring citizens' worldwide (Salah El-Din, 2013). Egypt had struggled with complex socio-economic and political problems that accelerated the 2011 revolution, such as social injustice, low living standards, reduced GDP, high unemployment, prevention of free elections, violations of human rights, factitious parliamentary elections, realizations of 'state of emergency', high corruption, and lack of transparency (EImassri et al., 2016, Corruption Perception Index, 2010). These factors motivated citizens to revolt against the Mubarak regime as they experienced its unfair treatment and its wealth centralization within his family and close associates (Salamey, 2015). On 25 January 2011, Egyptians went to Tahrir 
square to demand 'bread, freedom, social justice, and human dignity' but also President Mubarak's resignation (Wafa, 2015). Internet technology played a significant role in this revolution as Facebook and Twitter provided a platform for communication, syndicates and social movements such as 'Keyfaya' and '6 April', which called for people to gather and protest throughout the country (Mansour, 2012). After 30 days of protests, Mubarak stepped down and gave power to the Supreme Council of the Armed Forces (SCAF). The SCAF made some constitutional changes to offer Egyptians democracy and social justice, and it delegated power to a caretaker cabinet. However, Egyptians' social and economic expectations increased (e.g workers asked for more salaries, calls in streets from citizens to reduce prices, provide job opportunities, and more democracy) and strikes continued (Elmassri et al., 2016). Hence, on June 2012 the SCAF called for presidential election to satisfy public demands.

The 2011 revolution affected the Egyptian economy, particularly as the Egyptian stock market was closed from 28 January to 23 March 2011 to protect investors (Ahmed et al., 2015). The Egyptian government's bond ratings reduced by $75 \%$ in 2011, investment outflows amounted to nearly 4 billion Egyptian pounds, and share trading reduced sharply, which resulted in increasing debt to the US (Marzouk, 2016). Returns from tourism also deflated by almost $60 \%$ and the central bank declared that foreign currency reserves were marked down to a critical level ( from $\$ 36$ to $\$ 14,8$ billion by the end of 2012) (Elmassri et al., 2016). During the revolution, the Muslim Brotherhood gained legitimacy from the Egyptian public and became more influential among low-income and anti-Mubarak protestors. The group won most seats in the November 2011 parliamentary elections and Dr. Mohamed Morsi, the Muslim Brotherhood candidate, won the May 2012 presidential elections (Salah El-Din, 2013). Although expectations that Dr. Morsi's government would improve socio-economic and political situation, this was not realized (Salamy, 2015). Most Egyptians felt that they were deceived so revolted again in July 2013but this time against Dr.Morsi's presidency, and they brought his downfall. In Post Dr.Morsi's period, the SCAF's road map was adopted to fight the terrorism the Muslim Brotherhood and related organisations abroad effectuated. During this period, the abundant official speeches and pro-regime media accentuated external and internal threats to the country. The threat posed by the now called 'terrorist' by Muslim brotherhood was highlighted, and resistance 
to the regime was labelled a 'de-facto alliance' with the brotherhood that represented a 'fifth column' betraying Egypt (Sobhy, 2015, p.805). On 3 July 2014, the presidential election commission announced that Abdel Fattha Al-Sisi had won the free and fair presidential elections (State of Information Service, 2018). Additionally, in 2014, Egypt issued a new constitution that gave priority to social justice, human rights, equal opportunities, respect of local culture, social security of citizens, and freedom of beliefs (Egyptian Constitution, 2014). What is more, in 2015, President Sisi has released the sustainable development strategy of the country to start a new phase of development that line up social justice, urban development, environment, transparency of governmental institutions, education development, and national security (Egypt Sustainable Development Strategy 2030, 2015). Of significance here is the need to investigate change in the social reporting practices of Islamic banks, as social and economic institutions, before and after two revolutions via their websites and annual reports. The next section illuminates the methodology section.

\section{Methodology}

This research examines changes in volume, quality, and nature of social reporting practices by three major Islamic banks operating in Egypt before and after Arab uprisings in 2011 and 2013. For this purpose, this study adopts content analysis to investigate if certain themes in relation to social reporting are existent or absent in the Islamic banks' websites and annual reports in the pre-revolution period (2010) and post-revolution period (2016) (see appendix, table $X$, for their URLs). Content analysis method has been widely adopted in social reporting studies in analyzing different mediums of disclosure including annual reports and newspapers (Guthrie and Parker, 1990; Gray et al., 1995), only a few studies have previously used this methodology in analyzing Websites (e.g. Williams and Pei, 1999; Richardson et al., 2002; Bhasin, 2012). It is "a research technique for making replicable and valid inferences from texts (or other meaningful matter) to the contexts of their use" [Krippendorff, (2004), p.18]. Building a disclosure index (checklist) is recommended for this method and involves developing major categories and sub-categories. This checklist can be weighted or un-weighted (Tilt, 2002; Mardini et al., 2013). The main categories and subcategories of the disclosure index employed here deprived from understanding literature presented in the previous section, 
Global Reporting Initiatives (2013), social reporting literature in general and Islamic banks (Gray et al., 1995; Douglas et al., 2004; Kamla and Rammal, 2013; Akbar and Ahsan, 2014; Tradivo et al., 2017), and pilot investigation into Egyptian Islamic banks' Websites and press releases to reflect the political issues. By getting categories depending on the literature and the reality of disclosure, we have rational and trustable categories which can be analyzed and make our results generalizable (Krippendorff, 2004; Bhasin and Shaikh, 2013). Further, this research adopts unweighted disclosure $(0,1)$ like Brennan $(2001)$ study. The main categories are "Reference to Sharia", "Community Involvement, Zakat, and Quard Hassan", "Socially Responsible Products and Services", "Employees", "Political Incidents". "Political Incident" main category has been added to the index to reflect the Egyptian context in post revolution. The details of the index are in table 1 below. The main hypothesis of this study is as follows:

H: Egyptian Islamic Banks disclose more social information on their annual reports and websites after revolution to legitimize their existence in the Egyptian community.

There are sub-hypotheses under each main category:

H1: Egyptian Islamic banks disclose more information about sharia supervisory board report on their annual reports and websites after revolution than before.

H2: Egyptian Islamic banks report more information about community involvement, zakat, and charitable activities on their annual reports and websites after revolution than before revolution.

H3: Egyptian Islamic banks release more information about socially responsible products and services on their annual reportsandwebsitesafter revolution than before revolution.

H4: Egyptian Islamic banks report more information about employees on their annual reports and websites after revolution than before.

H5: Egyptian Islamic banks disclose more information about political incident on their websites and annual reports than before.

(Table 1. Social Reporting in Egyptian Islamic banks' Websites pre and post revolution)

The three websites of Islamic banks in Egypt are investigated to acquire the meanings of reporting, and to 
designate them to convenient categories. Adopting the conceptual and rational analysis approaches maintained insights into whether these practices are generally adopted by banks or are rare (Krippendorff, 2004). We adopted individual themes as units of analysis, which permitted us to look for issues relevant to social reporting in websites. We checked all areas of websites and annual reports of the three banks looking for any disclosures related to social reporting themes. These entail vision, about us, social activities, products and services, social responsibility, projects, SMEs, investor relations, zakat, quard hassan sections. Additionally, we used search facility option on the websites of Islamic banks to search for keywords like 'social', 'poverty', 'community', 'zakat', 'quard hassan', 'employees', 'Sharia', and 'microfinance'. Then, we evolved codes to help analyze the themes found in the websites and annual reports. The volume of CSR disclosure is measured by word count; type of CSR news disclosed on the websites is categorized into good, neutral, and bad news; and the nature of news reported is analyzed under qualitative, quantitative, monetary, pictures, videos, charts, graphs, tables, and videos (e.g. Guthrie and Parker, 1990; Williams and Pei, 1999). To ensure reliability of results, the researchers asked two other researchers to re-code the text using the same method and accordingly reduce inaccuracy and biases (Aribi and Gao, 2010).

\section{Findings and Discussion}

This section elaborates on findings and discussion under the five categories. Under the first category, we manifest the bank's reportings related to reference to Sharia. The other four categories highlight the themes reported in relation to the actual social activities. The final section provides conclusion of the results.

\section{Reference to Sharia}

This category entails any information about Sharia Supervisory Board (SSB) and how banks report their compliance with Sharia. The SSB is one of the distinctive features of Islamic banks. This is independent committee monitors the conduct of business and gives different assurance that business transactions are conducted in line with Islamic principles and norms (Aribi and Gao, 2010). Table 1 indicates accepting the first hypothesis as all Islamic banks disclose more information after revolution about reference to Sharia in annual reports and websites than before 
revolution. In 2016, most of banks disclosed more information in SSB report about examining documentations and procedures followed to execute the transactions in Sharia complaint, as well as disclosing how the board collected and inspected their evidences. Surprisingly, there is no reporting about how banks comply with Sharia in all its activities. Disclosures were all qualitative in nature, with neutral and good news type.

\section{Community Involvement, Zakat and Quard Hassan}

Disclosure under this main category covers items such as zakat issues (collection, expenses, and activities), charitable activities, quard Hassan, CSR commitment, human rights, and fighting terrorism. Table 2 demonstrates accepting the second hypothesis since there are more disclosures after revolution than before about this main category in the annual reports and websites. The results highlight that there are more disclosures after revolution on both mediums about zakat and charitable activities as a response to low socio-economic and poor quality of education and health services, because the government withdrew its social commitment in the post revolution era (Wafa, 2015). Faisal Islamic bank zakat fund pinpoints its contribution in alleviating the health issues after revolution as follows:

Out of the Zakat department's belief that interaction with the society is important, and because of more than 25 million persons in Egypt are infected with Hepatitis (C), an account has been opened for the purposes of liver transplant operations and treatment, and an amount of EGP 5 million has been allocated for liver transplant operations and treatment (Faisal Islamic bank Annual Report, 2016).

Further, Abu Dhabi Islamic Bank (ADIB) Egypt attempt to portray itself as a good citizen as follows:

ADIB Egypt is proud to have contributed to several charitable projects in the Delta and Upper Egypt regions that have benefited large segments of society: we contributed to the completion of construction of the Abrar Charity and Development complex in Bani Sareed Village, Sharqeyia (ADIB Egypt Website, 2016).

Similarly, Islamic banks increased their disclosures about quard Hassan by disclosing who the beneficiaries of such kind of loans are rather than mentioning the amounts spent on these loans 
before revolution. Faisal Islamic Bank -Egypt disclosed on its website policy in making such loans after revolution:

... in addition to, the Zaklat fund's legitimate channels, interest-free loans granted to the needy and people with urgent needs and who lived in difficult conditions, repayment of needy debtors' debts .... (Faisal Islamic Bank of Egypt, Annual Report, 2016)

Surprisingly, Al Baraka Bank Egypt and ADIB Egypt disclosed on their websites their responsibility towards human rights issues and fighting terrorism as a result of a new constitution in 2014 that gave more priority to such issues and changes of the culture in the Middle East:

... ADIB Egypt sponsorship of "Together against Hunger" embodies its dedication and commitment to the principles of Islamic Sharia to secure basic human rights, by ensuring adequate food access for one million people living below the poverty line... the bank do not finance criminal or terrorist activities (ADIB Egypt Website, 2016).

...our bank complies with protecting human rights...(Al Baraka Bank Egypt Annual Report 2016).

Moreover, Islamic banks stressed their commitment to CSR according to Islamic Sharia after revolution to legitimize themselves in the new context of new constitution and releasing a new sustainable development strategy; that focuses on social justice. Al Baraka Bank Egypt articulated its social role in the community as follows:

... the bank never neglected its social role as a pioneer Islamic foundation. It has always responded and reacted towards the society's financial needs since it performs its business based on the ethics derived from the tolerant Islamic Sharai ... the BOD established a (Social Responsibility Committee) and determined for it the programs, responsibilities and competencies to look after the activities of social responsibility... (Al Barak Bank Egypt, Annual Report, 2016)

Nevertheless, there is a need for more disclosures after revolution about the policy of Zakat fund in its spendings and who are the beneficiaries of this fund and the policy of quard hassan in determining the needy people. The predominant information under this category is qualitative, with monetary and qualitative information in nature. Additionally, the neutral and good news 
represent the common type of reporting. The next section explores socially responsible products and services. The next section explores socially responsible products and services.

\section{Socially Responsible Products and Services}

The Islamic banks should provide a high quality products and services and satisfy the needs of their clients while adopting Islamic Sharia. The Islamic teachings encourage the concept of Ihsan, "excellence" or "proper" (Siddiqui, 1997). Islam strengthens Ihsan in worship and work. The concept of worship in Islam includes "any constructive endeavor or work. This implies that a committed Muslim employee at organizational level should perform his/her behavior, even if the boss is not around" (Beekun and Badawi, 2005, p.134). The results manifest that disclosures about socially responsible products and services has the highest level in Islamic banks' websites and annual reports. This contradicts with the results of Hassan and Harahap (2010) in their analysis of other Islamic banks in the region. Table 1 expresses accepting the third hypothesis as Egyptian Islamic banks disclose more information about social responsible products and services in annual reports and websites after revolution than before revolution. After revolution, Egyptian Islamic banks gave more examples about their support to the national economy in infrastructure projects, as the state suffers from economic crisis after two revolutions in 2011 and 2013 and losing foreign currency reserve. Faisal Islamic Bank of Egypt reported the following in its website:

... to participate in getting the national economy moving forward by investing in vital projects in different sectors and consequently to enhancing the economic and social situation, as well as reducing the unemployment rates, improving the per capita income and redistributing the wealth in accordance with the bank's social responsibility (Faisal Islamic Bank of Egypt Website, 2016).

In the same vein, after revolution Egyptian Islamic banks enhanced their disclosures about microfinance projects and activities to alleviate the economic problems of Egyptians. For instance, Al Baraka Bank Egypt signed an agreement with the Social Development Fund (SDF) to fund SMEs projects as per Islamic Musharaka. Also, Egyptian Islamic banks disclosed more information about engagement in Mudarabah schemes such as banks' evaluations for Mudarabah products and balances of 
Mudarabah for individuals, corporate, and financial investments. They reported such kind of information to portray themselves as a good citizen in the Egyptian Islamic community that gave more priority to sharia adoption after revolution. Notably, Al Baraka Bank of Egypt is the only bank that highlighted its commitment to environmental accountability as the state started to give priority to environment after revolution according to sustainable development strategy. Uncommonly, these banks did not disclose information about policy towards insolvent clients and unlawful transactions. Under this main category, all news provided is neutral and good. Further, the majority of reportings are qualitative with some monetary, quantitative, pictures, and videos terms. The next section explores employees.

\section{Employees:}

Employee information is considered a key concern of employees and other stakeholders (Adams et al., 1995). This main category comprises details about employee benefits, equal opportunities, training schemes, training in relation to Sharia, appreciation and thanks, and workplace environment. The findings articulate accepting the forth hypothesis that indicate that Egyptian Islamic banks disclose more information about employees after revolution than before. Table 1 articulates that there are more disclosures about employee benefits and training schemes offered to employees to attract good quality staff, Particularly, Al Barak Bank Egypt disclosed more information about the average basic salary and rewarding systems linked to targets after revolution. What is more, all Egyptian Islamic banks reported details of training programs and stressed on the significance of training in developing the human capital. ADIB Egypt disclosed the following on its website:

... ADIB Egypt continued to focus on investing in staff training, learning and development with intent to improve the skills of its employees and to drive the bank towards delivering the best customer experience..... the bank offered tamakeen and qyidat programs to develop skills of staff in different levels (ADIB Egypt Annual Report, 2016).

Equally, Al Baraka Bank Egypt is the only bank that offered training programs on Sharia as follows:

... the bank offered training programs on Sharia to enhance the efficiency of the human resources... (Al Baraka Bank Egypt Annual Report, 2016) 
Moreover, Egyptian Islamic Bank disclose more information about appreciation and thanks to employees and workplace environment top legitimize themselves in the new Egyptian context after revolution that gave more priority to human rights, health and safety in the workplace, and human development (Egypt National Review Report, 2016). In this sense, Faisal Islamic Bank Egypt attempt to show itself as a good employer:

...Realizing more harmony between employees of different administrative levels and providing them with all the means to develop their abilities and efficiencies to meet their work requirements, and providing them with effective and fair systems of salaries, bonuses, and promotion opportunities in order to achieve a high level of job satisfaction (Faisal Islamic Bank of Egypt Website, 2016)

All employee information disclosed on the website and annual reports tends to be qualitative, with quantitative nature. All news is neutral. The following section shows disclosures about political incidents.

\section{Political Incident:}

This category represents the political incidents before and after two revolutions in Egypt. It includes any information in relation to political incidents and opportunities in realizing social cohesion and solidarity. Before revolution, most of concerns were about the negative impacts of the global financial crisis on the national economy, reduction in the development rate and Suez Canal returns, increasing unemployment, and uncertainty conditions that alarm for revolution. ADIB Egypt commented about the political and economic challenges:

... As I write this report, Egypt faces many political, economic and social challenges in the coming period, yet we remain optimistic about 2011 and beyond. The temporary setbacks that were experienced in the first half of 2011 will be mitigated by a period of recovery in the last quarter of 2011 as stability returns and Egypt moves a more transparent, democratic system of government... (ADIB Egypt, Annual Report, 2016).

However after revolution, Egyptian Islamic banks disclosed more information about the hard political and economic circumstances. As well as, they released information about social cohesion and 
solidarity as the new constitution in 2014 induces about these issues. Faisal Islamic Bank of Egypt highlighted about these hard conditions as follows:

... In 2016, there was a hard economic rules has been issued to deal with a decline in the indicators of the national economy as a result of two revolutions. One of the major decisions is currency flotation in the Egyptian currency. And, re-order the priorities of public spending with emphasis on enhancing the quality of health and education services (Faisal Islamic Bank of Egypt, Annual Report, 2016).

Additionally, ADIB Egypt elaborated its commitment to social justice after revolution:

.. stemming from ADIB Egypt's commitment to build bridges of social justice in this critical time in the country (ADIB Egypt Website, 2016)

All political incident information provides good and bad news in nature, with a qualitative and descriptive style. According to legitimacy theory, Egyptian Islamic banks adopted a "repairing strategy" in response to increasing social expectations, after two revolutions in 2011 and 2013 and releasing a sustainable development strategy in 2015 that gave more priority to social justice, supporting national economy, creating jobs, more compliance to Sharia and human rights, by reporting more information about "reference to Sharia", "Zakat collections, expenses and activities", "charitable activities and donations", "quard Hassan", "funding socially motivated and investment projects", "microfinance and microcredit schemes", "engagement with Mudarabah", "employee benefits", "training schemes", "appreciation and thanks", and "workplace environment". This is consistent with Patten's (1992) results that highlighted an increase in the level of environmental disclosures in terms of quantity to repair the legitimacy of the company. Surprisingly, Egyptian Islamic banks do not disclose information about "policy towards insolvent clients", "unlawful (Haram) transactions", "how banks comply with Sharia", "equal opportunities" and few reportings about "human rights", "fighting terrorism", and "environmental policy" after revolution. Thus, Egyptian Islamic banks seemingly adopted an "avoidance strategy" (e.g. Cho, 2009) - a result consistent with studies in other emerging economies (e.g. Coetzee and Van Staden, 2011). Such reporting behavior proposes that Egyptian Islamic banks may have recognized the sensitivity of 
information that may harm rather than help repair or maintain their legitimacy in a period of uncertainty, as well as the culture of secrecy in Arab countries (e.g. Elmassri et al., 2016; Dahawy et al., 2002). Egyptian Islamic banks adopted a "deflection strategy" by confirming their commitment to CSR, and addressing the political incidents happening before and after revolution, with initial disclosures about social inclusion and solidarity (e.g. Cho, 2009). Suchman (1995) implied that managers tend to deny problems related to negative incidents to alleviate the consequences. Nevertheless, there were public concerns as to whether Islamic banks could regain public trust following the 2011 and 2013 revolution and their failure to meet the increasing social expectations of Egyptians.

\section{Conclusion}

This research has inspected the volume, quality, and nature of Egyptian Islamic banks' social reporting before and after 2011 and 2013 revolutions in annual reports and websites. The results indicated accepting the main hypothesis as Egyptian Islamic banks reported more social information on annual reports and websites after revolution. Despite the severe pressure for social justice expectations after 2011 and 2013 revolutions, Egyptian Islamic banks tended not to or minimize their social reporting about how Islamic banks comply with Sharia, policy towards insolvent clients, unlawful (Haram) transactions, training in relation to Sharia, policy of zakat fund in its spending and beneficiaries, policy of quard Hassan in determining the needy people, equal opportunities, human rights, fighting terrorism, and workplace environment. This might be because such information potentially damages rather than benefits efforts to repair or maintain legitimacy (Villiers and Van Staden, 2006). The concurrent reporting guidelines in the central bank of Egypt and Egyptian stock market do not provide adequate information about what is classified as mandatory social reporting and how this should be reported. This study proposes that Egyptian government (and other Arab world governments) can further steps enhance the social disclosure guidelines and requirements to reflect social justice and well-being in business and to attract foreign investment into these countries. This paper's limitations as a case study includes focusing on annual reports and website analysis on the period before and after the 2011 and 2013 revolutions in Egypt, so the time frame was limited to information 
disclosed on Islamic banks' annual reports and websites in 2010 and 2016. Consequently, further studies are needed to explore different stakeholders' perceptions of social reporting in Arab spring countries after these uprisings can add additional dimensions and enrich the literature.

\section{References:}

Abdelsalam, O., Fethi, M. and Ausina, E. (2014) 'On The Comparative Performance of Socially Responsible and Islamic Mutual Funds', Journal of Economic Behavior and Organization, Vol. 103, pp.108 -128.

Abumustafa, N. (2017) 'Investigating the Arab Stock Markets during Arab Spring', Journal of Asset Management, Vol. 5, pp.313-318.

Adams, C., Coutts, A. and Harte, G. (1995) 'Corporate Equal Opportunities (non) Disclosure. The British Accounting Review, Vol.27 No.2, pp.87-108.

Aerts, W. and Cormier, D. (2009) 'Media Legitimacy and Corporate Environmental Communication', Accounting, Organizations and Society, Vol. 34, pp.1-27.

Aggarwal, R. and Yousef, T. (2000) 'Islamic Banking and Investment Financing', Journal of Money, Credit, and Banking, Vol. 32, pp.93-120.

Akbar, S. and Ahsan, K. (2014) 'Analysis of Corporate Social Disclosure Practices of Australian Retail Firms', International Journal of Managerial and Financial Accounting, Vol. 6 No. 4, pp.375-396.

Ahmed, H., Tahat, Y., Burtone, B. and Dunne, T. (2015) 'The Value Relevance of Corporate Internet Reporting: The Case of Egypt', Advances in Accounting, Vol.31, pp.188-196.

Al-Attas, S. (1996) 'The Worldview of Islam: An Outline' in AlAttas, S. (Eds.), Islam and The Challenge of Modernity, International Institute of Islamic Thought and Civilization, Kuala Lumpur, pp.89 - 95.

Aribi, Z. and Gao, S. (2011) 'Narrative Disclosure of Corporate Social Responsibility in Islamic Financial Institutions', Managerial Auditing Journal, Vol. 27 No. 2, pp.199-222.

Aribi, Z. and Gao, S. (2010) 'Corporate Social Responsibility Disclosure: A Comparison between Islamic and Conventional Financial Institutions', Journal of Financial Reporting and Accounting, vol. 8 No. 2, pp.79-91. 
Aribi, Z. and Gao, S. (2015) 'Corporate Social Responsibility and Islamic Financial Institutions (IFIs): Management Perceptions from IFIs in Bahrain', Journal of Business Ethics, Vol. 129 No.4, pp. 785 -804.

Avia, J. (2013) 'The Evolution of Corporate Social Responsibility (CSR) in The Arab Spring', The Middle East Journal, vol. 67 No. 1, pp.77-92.

Belal, A., Abdelsalam, O. and Nizamee, S. (2015) 'Ethical Reporting in Islamic Bank Bangladesh Limited (1983 -2010)', Journal of Business Ethics, Vol. 129, pp. 769 -784.

Beekun, R. and Badawi, J. (2005) 'Balancing Ethical Responsibility among Multiple Organizational Stakeholders: The Islamic Perspective', Journal of Business Ethics, Vol. 60 No. 2, pp.131145.

Ben Khediri, K., Charfeddine, L., and Ben Youssef, S. (2015) 'Islamic Versus Conventional Banks in The GCC: A Comparative Study Using Clarification Techniques', Research in International Business and Finance, Vol. 33 No. 6, pp.75-98.

Bhasin, M. (2012) 'Corporate Environmental Reporting on The Internet: An Exploratory Study', International Journal of Managerial and Financial Accounting, Vol. 4 No. 1, pp.78-103.

Bhasin, M. and Shaikh, J. (2013) 'Voluntary Corporate Governance Disclosures in Annual Reports: An Empirical Study', International Journal of Managerial and Financial Accounting, Vol. 5, pp.79 -105.

Chapra, U. (1992) Islam and the Economic Challenge. The Islamic Foundation, Leicester, UK.

Cho, C. (2009) 'Legitimation Strategies Used in Response to Environmental Disaster: A French Case Study of Total SA's Erika and AZF Incidents', European Accounting Review, Vol. 18 No. 1, pp. 33-62.

Corruption Perception Index: Transparency International. [Online]

http://www.transparency.org/cpi2010 (Accessed 5 September 2017)

Coetzee, C. and Van Staden, C. (2011) 'Disclosure Responses to Mining Accidents: South African Evidence', Accounting Forum, Vol. 35, pp.232-246.

Dahawy, K., Merino, B. and Conovor, T. (2002), 'The Conflict between IAS Disclosure Requirements and Secretive Culture in Egypt', Advances in International Accounting, Vol. 15, pp. 203228.

Dar, H. and Presely, R. (2000) 'Lack of Profit Loss Sharing in Islamic Banking: Management and Control Imbalances', 
International Journal of Islamic Financial Services, Vol. 2 No. 2, pp. 2-18.

Deegan, C. (2002) 'The Legitimizing Effect of Social and Environmental Disclosures - A Theoretical Foundation', Accounting, Auditing and Accountability Journal, Vol. 15 No. 3, pp. 282-311.

Deegan, C. and Rankin, M. (1996) 'Do Australian Companies Report Environmental News Objectively? An Analysis of Environmental Disclosures by Firms Prosecuted Successfully by The Environmental Protection Authority', Accounting, Auditing and Accountability Journal, Vol. 9, No. 2, pp. 52-69.

Deegan, C. and Unerman, J. (2011), Financial Accounting Theory, Second European Edition ed., McGraw Hill Education, New York, USA.

Douglas, A., Doris, J. and Johnson, B. (2004) 'Corporate Social Reporting in Irish Financial Institutions', The TQM Magazine, Vol. 16 No. 6, pp. 387-395.

Dusuki, A. and Abdullah, N. (2007) 'Why Do Malaysian Customers Patronize Islamic Banks?', International Journal of Bank Marketing, Vol. 25 No. 3, pp.142-160.

Egyptian Constitution (2014) the Constitution of the Arab Republic of Egypt 2014. Presidency Authority, Cairo, Egypt.

Egyptian Sustainable Development Strategy 2030 (2015) Sustainable Development Strategy: Egypt's Vision 2030 And Planning Reform. Ministry of Planning, Monitoring and Administrative Reform, Cairo, Egypt.

Elmassri, M., Harris, E. and Carter, D. (2016) 'Accounting for Strategic Investment Decision Making under Extreme Uncertainty', The British Accounting Review, Vol.48, pp.151 168.

Faisal Islamic Bank of Egypt (2016) Faisal Islamic Bank of Egypt Annual Report, Faisal Islamic Bank of Egypt, Cairo, Egypt.

Farook. S..,Hassan, M. and Lanis, R. (2011) 'Determinants of Corporate Social Responsibility Disclosure: The Case of Islamic Banks', Journal of Islamic Accounting and Business Research, Vol. 2, No. 2, pp. 114-141.

Fuzi, N., Habidin, N., Desa, A., Zamari, F. and Hibadullah, S. (2013) 'Corporate Social Responsibility Practices, ISO 26000 Efforts and CSR Performance in Malaysian Automotive Industry', International Journal of Managerial and Financial Accounting, Vol.5, pp.277 -293.

Gray, R., Kouhy, R. and Lavers, S. (1995) 'Corporate Social and Environmental Reporting: A Review of Literature and A 
Longitudinal Study of UK Disclosure', Accounting, Auditing and Accountability Journal, Vol. 8 No. 2, pp. 47-77.

GRI (2010) Global Reporting Initiatives of Sustainability and Transparency, Global Reporting Initiatives Organization, Amsterdam.

Guthrie, J. and Parker, L. (1990) 'Corporate Social Disclosure Practice: A Comparative International Analysis', Advances in Public Interest Accounting, Vol.3, pp.176-251.

Haniffa, R. and Hudaib, M. (2007) 'Exploring the Ethical Identity of Islamic Banks Via Communication in Annual Reports', Journal of Business Ethics, Vol. 76, pp.97-116.

Hassan, A. and Harahap, S. (2010) 'Exploring Corporate Social Responsibility Disclosure: The Case of Islamic Banks', International Journal of Islamic and Middle Eastern Finance and Management, Vol. 3, No. 3, pp. 203-227.

Hopper, T., Lassou, P. and Soobaroyen, T. (2017) 'Globalization, Accounting and Developing Countries', Critical Perspectives on Accounting, Vol. 43, pp. 125 - 148.

Kamla, R. (2009) 'Critical Insights into Contemporary Islamic Accounting', Critical Perspectives on Accounting, Vol. 20, pp. 921-932.

Kamla, R. and Rammal, H. (2013) 'Social Reporting by Islamic Banks: Does Social Justice Matter?', Accounting, Auditing and Accountability Journal, Vol. 26 No. 6, pp.911-945.

Kamla, R., Gallhofer, S. and Haslam, J. (2006) 'Islam, Nature and Accounting: Islamic Principles and The Notions of Accounting for The Environment', Accounting Forum, Vol. 30 No. 3, pp. 245-265.

Karim, R. (1990) 'The Independence of Religious and External Auditors in Islamic Banks', Accounting, Auditing and Accountability Journal, Vol. 3 No. 3, pp.34-43.

Khan, M. (2013) 'Developing a conceptual Framework to Appraise The Corporate Social Responsibility Performance of Islamic Banking and Finance Institutions', Accounting and The Public Interest, Vol. 13, pp. 191-207.

Krippendorff, K. (2004) Content Analysis: An Introduction to Its Methodology, Sage Publication Ltd, London, UK.

Lewis, M. (2001) 'Islam and Accounting', Accounting Forum, Vol. 25 No. 2, pp.103-127.

Maali, B., Casson, P. and Napier, C. (2006) 'Social Reporting By Islamic Banks"' ABACUS, Vol. 42, No. 2, pp. 266-289. 
Mansour, E. (2012) 'The Role of Social Networking Sites (SNSs) in The January $25^{\text {th }}$ Revolution in Egypt', Library Review, Vol.16, pp.pp.128 -129.

Mardini, G., Tahat, Y. and Power, D. (2013) 'Determinants of Segment Disclosures: Evidence from the Emerging Capital Market of Jordan', International Journal of Managerial and Financial Accounting, Vol.5, pp.253 -276.

Marzouk, M. (2016) 'Risk Reporting during Crisis: Evidence from the Egyptian Capital Market', Journal of Applied Accounting Research, Vol.17, pp.378 -396.

Megeid, N. (2013) 'The Impact of Service Quality on Financial Performance and Corporate Social Responsibility: Conventional versus Islamic Banks in Egypt', International Journal of Finance and Accounting, Vol. 2 No. 3, pp. 150-163.

O'Donovan, G. (2002) 'Environmental Disclosures in the Annual Report: Extending the Applicability and Predictive Power of Legitimacy Theory', Accounting, Auditing and Accountability Journal, Vol. 15 No. 3, pp. 344-371.

Patten, D. (1992) 'Intra-Industry Environmental Disclosures in Response to the Alaskan Oil Spill: A Note on Legitimacy Theory', Accounting, Organizations and Society, Vol. 15 No. 5, pp. 471-475.

Richardson, P., Anderson, A. and Bang, H. (2002) 'Sustainability Reporting on The Internet: A Study of Global Fortune 500', Greener Management International, Vol. Winter, pp.57-75.

Salah El-Din, A. (2013) 'The Causes of The Egyptian Youth's Participation in The Egyptian Spring of 2011 and June 2013', European Review, Vol. 12, pp.271 -277.

Salamey, I. (2015) 'Post-Arab Spring: Changes and Challenges', Third World Quarterly, Vol.36, pp.111-129.

Siddiqui, A. (1997) 'Ethics in Islam: Key Concepts and Contemporary Challenges'. Journal of Moral Education, Vol.26 No.4, pp.1-26.

Sobhy, H. (2015) 'Secular Façade, Neoliberal Islamisation: Textbook Nationalism from Mubarak to Sisi', Nations and Nationalism, Vol.21, pp. 805 -824.

State of Information Service Egypt. [online] http://wwwsisi.gov.rg/?lang=ar (Accessed 3 January 2018)

Suchman, M. (1995) 'Managing Legitimacy: Strategic and Institutional Approaches', Academy of Management Review, Vol. 20 No. 3, pp. 571-610. 
Tardivo, G., Bresciani, S. and Viassaaone, M. (2017) 'A Descriptive Framework for an Excellent Social Accountability', International Journal of Managerial and Financial Accounting, Vol. 9, pp.166-181.

Tilt, C. (2002) 'The Content and Disclosure of Australian Corporate Environmental Policies', Accounting, Auditing and Accountability Journal, Vol. 14 No. 2, pp. 190-212.

Uddin, S.,Siddiqui, J. and Islam, M. (2016) 'Corporate Social Responsibility Disclosures, Traditionalism and Politics: A Story from a Traditional Setting', Journal of Business Ethics, Vol. 136 No. 1, pp. 1-20.

Ullah, S. and Jamali, D. (2010) 'Institutional Investors and Corporate Social Responsibility: The Role of Islamic Financial Institutions', International Review of Business Research Papers, Vol. 6 No. 1, pp. 619-630.

Wafa, D. (2015) 'Arab Spring Impact on Excusive Education', International Journal of Education Management, Vol.29, pp.596 - 608 .

Warde, I. (2013) 'Islamic Finance in the Global Economy'. Paper presented at CFA Institute Middle East Investment Conference. Dubai.

Williams, S. and Pei, C. (1999) 'Corporate Social Disclosures by Listed Companies on Their Websites: An International Comparison', The International Journal of Accounting, Vol.34, pp.389-419.

Yekini, K., Adelpao, I., Andrikopoulos, P. and Yekini, S. (2017) 'Impact of Board Independence on Community Disclosure Quality', Accounting Forum, Vol.39 No.4, pp.249 -267.

Zinkin, J. (2007) 'Islam and CSR: A Study of The Compatibility Between The Tenets of Islam, The UN Global Compact and The Development of Social, Human, and Natural Capital', Corporate Social Responsibility and Environmental Management, Vol. 14 No. 4, pp.206-218. 
Table 1: Social Reporting in Egyptian Banks' Websites and Annual Reports

\begin{tabular}{|c|c|c|c|c|c|c|c|c|c|}
\hline \multirow{3}{*}{ Category } & \multirow{3}{*}{ Illustration } & \multicolumn{4}{|c|}{ Before (2010) } & \multicolumn{4}{|c|}{ After (2016) } \\
\hline & & \multicolumn{2}{|c|}{ Web } & \multicolumn{2}{|c|}{ Paper } & \multicolumn{2}{|c|}{ Web } & \multicolumn{2}{|c|}{ Paper } \\
\hline & & $\%$ & No( $\left.{ }^{*}\right)$ & $\%$ & No(*) & $\%$ & $\mathbf{N o}{ }^{(*)}$ & $\%$ & $\mathbf{N o}{ }^{(*)}$ \\
\hline 1.Reference to Sharia & $\begin{array}{l}\text { Information } \\
\text { about SSB, } \\
\text { how banks } \\
\text { report their } \\
\text { compliance to } \\
\text { sharia }\end{array}$ & 100 & 300 & 100 & 484 & 100 & 1,200 & 100 & 1,446 \\
\hline Total & & 100 & 300 & 100 & 484 & 100 & 1,200 & 100 & 1,446 \\
\hline \multicolumn{10}{|c|}{ 2.Community Involvement, Zakat, and Quard Hassan } \\
\hline $\begin{array}{l}\text { 2.1.Zakat collection, } \\
\text { Expenses, and } \\
\text { Activities }\end{array}$ & $\begin{array}{l}\text { It includes all } \\
\text { information } \\
\text { related to } \\
\text { zakat fund }\end{array}$ & 67 & 327 & 67 & 1,460 & 67 & 450 & 67 & 1,686 \\
\hline $\begin{array}{c}\text { 2.2. Charitable Activities } \\
\text { and Donations }\end{array}$ & $\begin{array}{l}\text { Details about } \\
\text { education, } \\
\text { health, and } \\
\text { support to any } \\
\text { kind of } \\
\text { marginalized } \\
\text { and vulne- } \\
\text { rable groups }\end{array}$ & 100 & 631 & 100 & 800 & 100 & 1,375 & 100 & 1,000 \\
\hline 2.3.Quard Hassan & $\begin{array}{l}\text { Any inform- } \\
\text { ation related to } \\
\text { sources, uses, } \\
\text { and policy of } \\
\text { Quard Hassan }\end{array}$ & 67 & 18 & $\mathbf{0}$ & $\mathbf{0}$ & 67 & 110 & 67 & 200 \\
\hline 2.4.Human Rights & $\begin{array}{l}\text { Any inform- } \\
\text { ation related to } \\
\text { human rights } \\
\text { issues }\end{array}$ & $\mathbf{0}$ & $\mathbf{0}$ & $\mathbf{0}$ & $\mathbf{0}$ & $\mathbf{0}$ & $\mathbf{0}$ & 67 & 20 \\
\hline 2.5.Fighting Terrorism & $\begin{array}{l}\text { Any informa- } \\
\text { tion pertinent } \\
\text { to fighting } \\
\text { terrorism }\end{array}$ & $\mathbf{0}$ & $\mathbf{0}$ & $\mathbf{0}$ & $\mathbf{0}$ & $\mathbf{0}$ & $\mathbf{0}$ & 33 & 5 \\
\hline 2.6.CSR Commitment & $\begin{array}{l}\text { Any details } \\
\text { related to } \\
\text { commitment of } \\
\text { the bank to } \\
\text { CSR }\end{array}$ & 67 & 86 & 33 & 120 & 100 & 208 & 67 & 250 \\
\hline Total & & 100 & 1,062 & 100 & 2,380 & 100 & 2,143 & 100 & 3,161 \\
\hline
\end{tabular}

${ }^{(*)}$ No. $=$ No. of Words. 


\begin{tabular}{|c|c|c|c|c|c|c|c|c|c|}
\hline \multirow{3}{*}{ Category } & \multirow{3}{*}{ Illustration } & \multicolumn{4}{|c|}{ Before (2010) } & \multicolumn{4}{|c|}{ After (2016) } \\
\hline & & \multicolumn{2}{|c|}{ Web } & \multicolumn{2}{|c|}{ Paper } & \multicolumn{2}{|c|}{ Web } & \multicolumn{2}{|c|}{ Paper } \\
\hline & & $\%$ & No(*) & $\%$ & No(*) & $\%$ & No(*) & $\%$ & $\mathbf{N o}^{(*)}$ \\
\hline \multicolumn{10}{|c|}{ 3.Socially Responsible Products and Services } \\
\hline $\begin{array}{l}\text { 3.1.Funding socially } \\
\text { Motivated } \\
\text { Investment } \\
\text { Projects }\end{array}$ & $\begin{array}{l}\text { Information } \\
\text { about funding } \\
\text { infrastructure } \\
\text { projects, } \\
\text { public } \\
\text { projects, } \\
\text { taking into } \\
\text { account social } \\
\text { and } \\
\text { environmental } \\
\text { dimensions in } \\
\text { investment } \\
\text { decisions } \\
\end{array}$ & 67 & 50 & $\mathbf{0}$ & $\mathbf{0}$ & 100 & 300 & 100 & 500 \\
\hline $\begin{array}{l}\text { 3.2. Microfinance and } \\
\text { Microcredit } \\
\text { Schemes }\end{array}$ & $\begin{array}{l}\text { Details about } \\
\text { microcredit } \\
\text { and } \\
\text { microfinance }\end{array}$ & 100 & 200 & 100 & 900 & 100 & 400 & 100 & 1100 \\
\hline $\begin{array}{l}\text { 3.3.Engagement with } \\
\text { Mudarabah }\end{array}$ & $\begin{array}{l}\text { Any } \\
\text { information } \\
\text { about } \\
\text { Mudarabah } \\
\text { programs } \\
\end{array}$ & 100 & 454 & 100 & 1550 & 100 & 713 & 100 & 3900 \\
\hline $\begin{array}{l}\text { 3.4.Environmental } \\
\text { Policy }\end{array}$ & $\begin{array}{l}\text { Details about } \\
\text { the } \\
\text { environmental } \\
\text { attitude of the } \\
\text { bank } \\
\end{array}$ & $\mathbf{0}$ & $\mathbf{0}$ & $\mathbf{0}$ & $\mathbf{0}$ & $\mathbf{0}$ & $\mathbf{0}$ & 33 & 14 \\
\hline $\begin{array}{l}\text { 3.5.Policy Towards } \\
\text { Insolvent Clients }\end{array}$ & $\begin{array}{l}\text { Details about } \\
\text { insolvent } \\
\text { clients and } \\
\text { policies } \\
\text { towards them }\end{array}$ & $\mathbf{0}$ & $\mathbf{0}$ & $\mathbf{0}$ & $\mathbf{0}$ & $\mathbf{0}$ & $\mathbf{0}$ & $\mathbf{0}$ & $\mathbf{0}$ \\
\hline $\begin{array}{c}\text { 3.6.Unlawful (Haram) } \\
\text { Transactions }\end{array}$ & $\begin{array}{l}\text { Specifics about } \\
\text { unlawful } \\
\text { (Haram) } \\
\text { transactions }\end{array}$ & $\mathbf{0}$ & $\mathbf{0}$ & $\mathbf{0}$ & $\mathbf{0}$ & $\mathbf{0}$ & $\mathbf{0}$ & $\mathbf{0}$ & $\mathbf{0}$ \\
\hline Total & & 100 & 704 & 100 & 2450 & 100 & 713 & 100 & 5514 \\
\hline \multicolumn{10}{|l|}{ 4. Employees } \\
\hline 4.1. Employee Benefits & $\begin{array}{l}\text { Benefits to } \\
\text { employees } \\
\text { including } \\
\text { salaries, } \\
\text { healthcare..etc }\end{array}$ & 33 & 30 & 33 & 70 & 67 & 122 & 100 & 270 \\
\hline
\end{tabular}




\begin{tabular}{|c|c|c|c|c|c|c|c|c|c|}
\hline \multirow{3}{*}{ Category } & \multirow{3}{*}{ Illustration } & \multicolumn{4}{|c|}{ Before (2010) } & \multicolumn{4}{|c|}{ After (2016) } \\
\hline & & \multicolumn{2}{|c|}{ Web } & \multicolumn{2}{|c|}{ Paper } & \multicolumn{2}{|c|}{ Web } & \multicolumn{2}{|c|}{ Paper } \\
\hline & & $\%$ & No(*) & $\%$ & $\mathbf{N o}^{(*)}$ & $\%$ & $\mathbf{N o}^{(*)}$ & $\%$ & $\mathbf{N o}^{(*)}$ \\
\hline $\begin{array}{l}\text { 4.2.Equal } \\
\text { Opportunities }\end{array}$ & \begin{tabular}{|l|} 
Information \\
related to \\
equal \\
opportunities \\
practices \\
\end{tabular} & $\mathbf{0}$ & $\mathbf{0}$ & $\mathbf{0}$ & $\mathbf{0}$ & $\mathbf{0}$ & $\mathbf{0}$ & $\mathbf{0}$ & $\mathbf{0}$ \\
\hline 4.3. Training Schemes & $\begin{array}{l}\text { Any reference } \\
\text { to training } \\
\text { programs }\end{array}$ & 33 & 120 & 67 & 100 & 67 & 200 & 100 & 546 \\
\hline $\begin{array}{l}\text { 4.4. Training in } \\
\text { relation to Sharia }\end{array}$ & $\begin{array}{l}\text { Training } \\
\text { programs in } \\
\text { relation to } \\
\text { Sharia }\end{array}$ & $\mathbf{0}$ & $\mathbf{0}$ & $\mathbf{0}$ & $\mathbf{0}$ & $\mathbf{0}$ & $\mathbf{0}$ & 33 & 10 \\
\hline $\begin{array}{l}\text { 4.5.Appreciation and } \\
\text { Thanks }\end{array}$ & $\begin{array}{l}\text { Any reference } \\
\text { to respect and } \\
\text { thanks to } \\
\text { employees. }\end{array}$ & 33 & 40 & 67 & 70 & 67 & 100 & 100 & 150 \\
\hline $\begin{array}{l}\text { 4.5. Workplace } \\
\text { Environment }\end{array}$ & $\begin{array}{l}\text { Strategies } \\
\text { related to } \\
\text { work-life } \\
\text { balance, } \\
\text { effective } \\
\text { employee } \\
\text { communication }\end{array}$ & 33 & 30 & $\mathbf{0}$ & $\mathbf{0}$ & 33 & 50 & 67 & 80 \\
\hline Total & & 33 & 301 & 67 & 260 & 67 & 472 & 100 & 1056 \\
\hline 5.Political Incidents & $\begin{array}{l}\text { Any reference } \\
\text { to political } \\
\text { incidents, } \\
\text { social cohesion } \\
\text { and solidarity }\end{array}$ & $\mathbf{0}$ & $\mathbf{0}$ & 100 & 1000 & $\mathbf{0}$ & $\mathbf{0}$ & 67 & 1,100 \\
\hline
\end{tabular}

\section{Appendix}

Table 1: List of Egyptian Islamic Banks' Websites

\begin{tabular}{|l|l|}
\hline \multicolumn{1}{|c|}{ The Bank } & \multicolumn{1}{c|}{ URL } \\
\hline $\begin{array}{l}\text { Faisal Islamic } \\
\text { Bank of Egypt }\end{array}$ & http:www.faisalbank.com.eg/FIB/English/index.html \\
\hline $\begin{array}{l}\text { Al Baraka Bank } \\
\text { Egypt }\end{array}$ & http://www.albaraka-bank.com.eg/en \\
\hline $\begin{array}{l}\text { Abu Dhabi } \\
\text { Islamic Bank } \\
\text { Egypt }\end{array}$ & http://www.adib.eg/ \\
\hline
\end{tabular}

